\title{
The Implementation of National Values Insights in the Learning Process of Indonesian History to Form Student's Solidarity Attitudes
}

\author{
Tri Endaryati (Corresponding author) \\ History Education, Graduate School, Yogyakarta State University, Indonesia \\ E-mail: triendaryati.2018@student.uny.ac.id
}

Aman

History Education, Graduate School, Yogyakarta State University, Indonesia

E-mail: aman@uny.ac.id

Johan Setiawan

Graduate School, Yogyakarta State University, Indonesia

E-mail: johansetiawan767@gmail.com

Received: April 6, 2020 Accepted: April 27, 2020 Published: May 31, 2020

doi:10.5296/ijld.v10i2.17125 URL: https://doi.org/10.5296/ijld.v10i2.17125

\begin{abstract}
The purpose of this study was to determine the implementation of values national insight within Indonesian history's learning process to form students' solidarity attitudes at Senior High Schools in Yogyakarta. This research was a case study by using qualitative approach. Data collection techniques consisted of observation, interviews, and documentation. The results of the study stated that the implementation of values national insight in the learning process of Indonesian history to form an attitude of solidarity could be conducted through the stages of learning planning by compiling a learning device in the form of a syllabus and learning implementation plan (RPP). The implementation of learning was carried out through Indonesian history material containing values of national insight which was expected forming an attitude of solidarity. During study, the arising problem was teacher's to carry out the
\end{abstract}


learning process and students' lack of less attention on the teaching material.

Keywords: National Insight, Learning of Indonesian History, Solidarity Attitude

\section{Introduction}

Indonesian nation is a pluralistic nation which consists of various ethnic groups, races, religions and cultural systems (Lestariningsih, 2018). Indonesian people's identity cannot be separated from the diversity of its people. As a pluralistic nation, cooperative attitude is needed to embrace all groups. There should be respect between groups in order to live side by side peacefully (Omar, 2015). In other words, there should be solidarity between tribes, religions and cultures in carrying out their lives (Alfulaila, 2019).

However, the rapid flow of globalization which actually has a negative impact on the diversity of Indonesia is considered to be Indonesia's biggest challenge. Technological and information advances have led to the national phenomenon namely as the tendency of solidarity attitude degradation. The fading spirit of nationalism is due to: the desire of some regions to separate themselves from the Republic of Indonesia; the strengthening spirit of primordialism; the growth of separatist symptoms; and the use of force and coercion on the basis of majority causing inter-ethnic conflict (Sofyan, 2017).

Seeing this phenomenon, it is not surprising that conflicts often occur between ethnic and religious conflicts in several regions in Indonesia, for example as happened in Maluku, Central Kalimantan and Poso (Adam, 2010). The conflict indicates that the sense of integrity and unity of the Indonesian people is questionable.

Globalization which is accompanied by a revolution on the field of Information and Communication Technology has an impact on the fading value of solidarity among high school students. High school students as the young generation of Indonesia who are the backbone of the nation have been poisoned by various impacts of globalization (Wulandari, 2010).

The fading solidarity among students is characterized by a lack of respect for diversity and difference, lack of cooperation, mutual cooperation and a sense of solidarity between people (Anwar, 2017; Kinasih, 2018; Meeusen, 2019). Education is the main key to Indonesian people's life as an effort to educate the nation's children (Novianti, 2017; Saraswati; 2011; Zambeta, 2014).

One form of education to answer this challenge is by implementing national insights on the Indonesian history subject at high school level. Indonesian history is a subject that instills knowledge, attitudes, and values regarding the process of change and development of Indonesian society (Almisad, 2009; Loreto, 2019; Seixas, 2005; Wibowo, 2015).

Indonesian history learning process in schools needs to be carried out to build scientific understanding from the perspective of time, shared memory, and awareness of the nation's core values. Historical learning as an element of cultural solidarity development works as a medium in establishing relationships between elements of society in Indonesia that are pluralism (Arts, 2001; Minelgait, 2017). 


\section{Macrothink}

The values of nationalism insight can be applied through history learning in schools (Anis, 2017). Indonesian history lessons that implements the values of national insight in Indonesian history learning materials are very important to instill nationalism and state attitudes (Banks, 2017; Sudiatmi, 2019), which contains the values of accepting and diversity, tolerance, integrity and national unity, and fostering awareness for the crisis of solidarity due to Indonesia's pluralism (Matsaganis, 2011). These values are part of the national outlook (Davis, 2003; Wibowo, 2020).

The characteristics of Indonesian history subjects in high schools according to Aman (2011) have a strategic meaning on the formation of dignified character and nation's civilization and on the formation of Indonesian people who have the values of nationalism insight through the teaching of solidarity (Zambeta, 2003). Because in Indonesian history, the unity which has been established by Indonesian youths' solidarity is depicted by the 1928 youth oath event.

The implementation the values of national insights through the study of Indonesian history to form students' solidarity attitude and to face globalization flows becomes important, due to its operational nature and its rare implementation. Previous research has focused to form nationalism attitudes (Anggraeni, 2016) and focus on character (Misbahudholam, 2016). Therefore, this study intend to examine the implementation of national insight values in the learning of Indonesian history to form students' solidarity attitude. The purpose of this study was to determine the implementation of values national insight within Indonesian history's learning process to form students' solidarity attitudes at Senior High Schools in Yogyakarta.

\section{Theoretical Review}

\subsection{Implementation on National Insights Values}

According to Nasikun (2006) the concept of national insight was an ideological movement. It never raised without the events that preceded it. Nationalist insight was understood as a consequence of the emergence of awareness of shared suffering under colonialism, imperialism. Nationality insight of Indonesian people united various ethnic groups. National insight growth as the identity of the historical process and cultural patterns that are diverse and diverse, but still in unity. According Rahayuningsih (2009) national insight was a national integrity, in the sense of attitudes and perspectives as a whole of national archipelago and national interest.

Therefore, it could be concluded that national insight was an attitude and action that did not reflect differences in ethnicity, religion, culture, race, class and so on without any reason which could be seen from the attitudes and actions that respect and respect any differences. It aimed to maintain the unity and integrity of the nation in order to remain united in diversity. This was in the context of maintaining mutual solidarity between students as good Indonesian citizens (Beal, 2014).

National insight was a way of looking at the Indonesian people towards themselves and their environment based on Pancasila, the 1945 Constitution, Unity in Diversity and the Unitary Republic of Indonesia which aims to increase the attitude of solidarity on the basis of the awareness of the nation's citizens in the territory of the Republic of Indonesia. Thus according 
to Widayanti (2018) in the concept of nationality, there were several elements or characteristics, including nationalism, nationalism and national spirit.

National insight was oriented to ways of thinking, which operationally referred to the values and norms of community and national life, based on a deep understanding of worldviews, historical backgrounds, geographical conditions, arts and languages. Nationalism insight was oriented towards attitudes which were instilled through the habit of responding to historical events or circumstances related to social and national life including: acceptance and respect for differences, ancestral origins, and Indonesian ethnicity. The national spirit of orientation toward behavior was referred to the dynamics of attractive behavior in the act of the same fate and continuity, tolerance, mutual respect, and showed pride as an Indonesian nation. Indonesia, which consisted of diverse cultures, ethnics, and religions, was regarded as pluralistic nation. The elements or characteristics of nationality insight should be possessed by Indonesian people, especially the younger generation through education in high school, one of them was through the lessons of Indonesian history.

\subsection{Indonesia's History Learning Concept}

According to Vlekke (2008) Indonesian history was a historical event in various regions of Indonesia, which began from the pre literacy era until now. The history of Indonesia can be defined as the history of the Indonesian people or the history of the Indonesian archipelago. Ricklefs (2009) stated that Indonesian history was an event which was occurred a thousand years ago or in the pre literacy period in various regions of Indonesia or until they reached a present time or commonly known as the reformation period.

Indonesian history according to Abdullah (2011) was a depiction of various events in Indonesia that covered a very long time span. The period of Indonesian history began in pre literacy, the Hindu-Buddhist kingdom which included the entry and the development of Hindu-Buddhist influence in Indonesia; the arrival and civilization of Islam; colonization and resistance; and also the period of western and Japanese colonization in Indonesia; and the emergence of popular resistance to colonialism.

The period of nationalist movement included the birth of national organizations and the emergence of intellectuals to achieve independence. Furthermore, the war and revolution included defending Indonesian independence from within and from abroad, and post-revolution which encompassed a period of liberal and guided democracy, the new order era, and the reform era.

The subjects of Indonesian history taught in high school according to Kochhar (2008) were aimed at teaching solidarity. By studying about various historical events in Indonesia to build collective memory in students, so that they would know the history of their nation, were able to recognize their national identity, and made it a foundation in building national and state life in the present and the future.

\subsection{Forming Solidarity Attitudes}

Attitude according to Slameto (2013) was something which was learned, and attitudes 
determined how individuals react to situations and what individuals look for in life. Attitude was closely related to behavior or action. According to Chaiklin (2011) attitude was closely related to a person's situation in acting on an existing fact. This action provided a certain behavior which came out of a person because of what he/she had done.

It could be concluded that attitude was an act or behavior of a person regarding an object which was accompanied by certain feelings and provided a basis for someone to behave in accordance with his will which was good or bad in establishing an interaction with others. If the concept of attitude was understood, then the concept of solidarity would come next.

According to Crow (2002) solidarity was the basis of our permanent understanding of unity, friendship, mutual trust which came from shared responsibilities and interests among members. According to Emile Durkheim himself, solidarity was commonality which referred to a state of relationship between individuals and/or groups based on moral feelings and shared beliefs reinforced by shared emotional experiences (Jones, 2009).

According to him, the attitude of solidarity was divided into two. First, mechanics was solidarity based on equality. It was the similarities and tendencies for uniformity that formed the social structure of segmented societies where the societies were homogeneous and similar to each other. The second was organic solidarity, which was solidarity that bound an already complex society and had been recognized as an organized division of labor which was united by interdependence among members. Usually this solidarity was found in urban communities. Organic solidarity occurred because there was a difference.

The attitude of solidarity which was well embedded in the students of at Senior High Schools in Yogyakarta, would foster a positive attitude among students themselves. Therefore, if something was indeed good, students would carried it out throughout his life and students would act according to the attitude of solidarity that he believed. This was marked by placing the unity and integrity of the nation above personal or group interests, for example by willing to sacrifice for the interests of the nation and state, and developing an attitude of tolerance to uphold diversity in the school environment. The forms of solidarity were such Das maintaining mutual solidarity between peers, mutual cooperation and mutual cooperation. This attitude of solidarity could be formed in schools through the Indonesian history lesson (Lestari, 2018).

\section{Method}

The type of this research was qualitative research (Lexy, 2011). The approach used was a case study which was conducted at Class XI of Senior High Schools in Yogyakarta. The research was conducted on October 12 until December 11, 2020. Data collection techniques was carried out by using three techniques, namely observation, interviews and document methods (Sutopo, 2006). Determination of informants using purposive sampling and then developed again with the snowball technique that is information determination with help informants main that is his history teacher class XI and suggested other informants from class XI student amounted four. Furthermore, data validity test was done by two triangulation techniques, namely source triangulation and technical triangulation. Source triangulation was carried out by interviewing informants namely 2 Indonesian history teacher. Pseudonym is Teacher Siti and Teacher 
Aptinah and 4 students of class XI IPS. Technical triangulation was done by checking the same data in different ways. Technical data analysis use a model Miles and Huberman (2017) consisted of data reduction, data presentation and verification. Data reduction was administered to classify data from observations, interviews, and documentation. The presentation of the data was conducted after data reduction, which was presented in the form of descriptive text. Next, analysis was as a mean to draw conclusions or verification by looking at the relationship meaning of data obtained from observations, interviews, and documentation.

\section{Result and Discussion}

\subsection{Implementation the Values of National Insight in the Prosess of Learning Indonesian History to form an attitude of Solidaity}

\subsubsection{Planning of Indonesian History Learning based on the Insights of National Values}

At the planning stage of the Indonesian history teacher at Senior High Schools in Yogyakarta, teacher could prepare Syllabus and RPP containing national character that internalized the values of national insights, such as the attitude of accepting/appreciating diversity, integrity, values of love, tolerance, national unity and integrity, and an attitude of solidarity, yet the most important thing was how Indonesian historical material could form a solidarity attitude.

Before starting a lesson in the class, teacher could give an a perception in the form of greetings and checking students' attendance to fill journals in the classroom. This happened in all classes that researchers met in the study namely class XI IPS 1 and XI IPS 2 which were supported by Teacher Siti and Teacher Aptinah. After that the researcher as an observer was invited by the teacher to give an introduction in front of the class. Then, the teacher explained researcher's intention and purpose.

In implementing nationalism insight's values on the learning of Indonesian history to form students' solidarity attitude, a teacher should better understand the concept of nationalism insight itself. By having a good understanding of these values, the teacher would have an ease to prepare syllabus and lesson plans in the learning process such as loading the material and its assessment (Najib, 2013). It should be containing historical material that could shape students' own solidarity attitudes.

The results of a research interview with Teacher Siti, she stated: "The examples of material that emphasized the values of nationalism which could build an attitude of solidarity was such as, the material of Indonesia's national history revival. The syllabus and RRP material were material that contained the values of solidarity." So that it could be seen that the learning of Indonesian history at Senior High Schools in Yogyakarta was a national insight based learning which could shape students' solidarity attitudes.

\subsubsection{The Implementation of Indonesian History Learning Based on National Values Insights}

The implementation of Indonesian history learning based on the values of national insight at Senior High Schools in Yogyakarta could be observed in several aspects. For example in Core Competencies (KI) 3 and Basic Competencies (KD) 3.4, teachers could ask students to analyze the similarities and differences in approaches and strategies of national movements in 
Indonesia at the beginning of the national awakening, the Youth Pledge and thereafter until the Proclamation of Independence. The material on the history of Indonesia's national revival was marked by the establishment of various national organizations such as Budi Otomo and the existence of youth oaths. It demonstrated unity because Indonesia was a unitary state consisting of diverse ethnic, cultural and religious groups which was shown by its motto "Unity in Diversity".

A slogan which had a deep philosophical meaning, was the connecting tie of Indonesian people in the unity of Indonesia, one homeland, one nation and one language. It was later on considered to be the origin of he Youth Pledge (Budiwati, 2012). The youth oath showed the insight of nationality on the determination and desire to build unity and integrity because it was aware of Indonesia's diversity that covered the diversity of cultures, religions, ethnics, and tribe for Indonesian independence in the future.

Through this oath, the youth promised to have the same feelings as having one nation, one country and one language, namely Indonesia (Subaryana, 2012). All of this had upheld the spirit of togetherness to fight against the invaders by uniting steps in the same direction to achieve independence. Morover, it was conducted by maintaining national unity and integrity which was resulting from the solidarity of Indonesian youths from various regions (Suhady \& Sinaga, 2006).

The basic values of the nationalist insight of solidarity were used as a strength to fix the Indonesian nation in fostering national identity by implementing it. These things should be able to be understood by the Indonesian people to form a solidarity attitude as a new color in providing concrete solutions for the Indonesian nation (Anggraeni, 2016).

In order to easily provided understanding and instilled the values containing Indonesian history, teachers should use appropriate learning strategies. It was a series of actions which were effective, planned, and directed in order to achieve the goals and objectives of learning. Then, the lessons of Indonesian history should also be designed to develop a knowledge, understanding, and analytical ability towards the past and social conditions of Indonesian society.

Basically, Indonesian history learning functioned to raise awareness in students. The existing awareness of students would make students full of dedication and would have love for their people. The results of a research interview with Teacher Aptinah, she stated: "that the strategy adopted in the cultivation of the values of nationalism through history learning was to provide a history of Indonesian history to give students real time experience and active learning approaches."

Furthermore, it could conducted through question and answer session, and discussion. This was performed by Indonesian history teachers when they gave questions to students between lectures. This method was expected to attract the interest and motivation of students. Especially when teachers delivered long material students would feel bored or tired, or even sleepy. However, when teachers combined it with questions and answers, students were motivated to pay attention more to the teaching material, especially if the students' answers were assessed by 
the teacher (Anis, 2017). Based on the above analysis, teachers at Senior High Schools in Yogyakarta had implemented a learning strategy which instilled the values of nationalism in the study of Indonesian history to form an attitude of solidarity. The strategy included the preparation of the syllabus, lesson plans (RPP), methods, and media that had been used previously.

Based on the results of a research interview with four students of class XI: "The implementation of national insight into the learning of Indonesian history at Senior High Schools in Yogyakarta was proven to be went well. This was because almost all of the students interviewed answered that they had "been delivered" with the question "did your Indonesian history teacher allude to the issue of national values insights". The result was seen from the answers of five students who have been interviewed."

The interview was carried out in the classroom stage. Interviews were conducted with random students. Students could cite real examples on the application of nationalism values that could form an attitude of solidarity in their lives such as respecting fellow friends, not choosing to make friends, and cooperating/working with each other.

\subsection{Factors that are Constraints in the Process of Implementing national insights values on Indonesian History Learning at Senior High Schools in Yogyakarta}

\subsubsection{The Ability of Teachers in the Process of Learning Indonesian History}

Teachers could ask students to analyze the similarities Teacher should be able to bring past events into the learning process. But because these events have occurred and could not be repeated, the teacher's ability was needed to imagine and visualize so students could understand and took meaning from the presented events. This was a challenge for Indonesian history teachers to show that Indonesian history was a very important for students to be learned ad understood (Anis, 2017).

Based on the results of a research interview with Indonesian history Teacher Siti, she shared: "The factor that constrained teachers in internalizing the values of national insight on the learning Indonesian history was the lack of students knowledge in understanding new terms and students only own small understanding between one culture and one other cultures, especially in customs."

Through learning Indonesian history teachers could provide solutions and explained things which were not understood by students. So students would understand and realized the values of national insights that could help them live in society. In addition, teachers were required to be able to foster motivation to learn history so that in turn students were able to understand the meaning of history for their lives both now and in the future. The quality of history learning, one of which should be supported by the performance of teachers required s lot of thought, time and energy to do the planning, implementation and assessment (evaluation).

\subsubsection{The Attitude of Students in Learning Indonesian History in Class}

The obstacle of Indonesian history subject teachers in instilling the values of national insight to form an attitude of solidarity through the learning process in reality did not only come from the 
teacher, but also from students (Najib, 2013). The results of a research interview with Indonesian history teacher class XI Mrs. Aptinah, she stated: "Student activities at Senior High Schools in Yogyakarta which was very dense would make you tired, so that it would impact on learning activities in the classroom. This condition made some students paid less attention to the material. Then, the teacher should be able to apply various models, strategies or teaching methods so that there were variations when delivering the material."

The existence of variations in learning meant that it would be able to bring students to remain passionate in learning and will always give positive responses to the material they receive (Setiawan, 2020). Students who have a positive attitude (active) during teaching and learning activities basically have a higher enthusiasm and motivation to learn compared to students whose attitudes are negative (passive). Therefore, high learning motivation in students would be followed by higher learning intensity ultimately that their learning achievement would also be higher than before. Thus, the quality of the process and the results of historical learning were also be influenced by the attitude of the students when the teaching and learning activities took place.

\section{Conclusion}

The implementation of the values of insights national in learning Indonesian history to form an attitude of solidarity begins at the planning stage. Indonesian history teacher at Senior High Schools in Yogyakarta has internalized the values of national insight into the syllabus and lesson plans that teachers has already compiled. At this stage, the teacher designs the steps of Indonesian history learning that facilitate active students from the introduction, core, and closing. The teacher implements the values of national insight in the implementation of historical learning through material related to national insight and uses a variety of learning methods. By using methods that can activate students' brain, it will facilitate the process of implementing national insight in the history of learning to form students' attitudes of solidarity. The process of learning history based on national insights at Senior High Schools in Yogyakarta starts from the planning, implementation and assessment stages. Last, the process of learning Indonesian history based on national insight will succeed if it can overcome problems both from the teacher and students.

\section{Acknowledgements}

Thank you to all experts and teachers participated in this research. Hopefully, the results of this research are useful in learning.

\section{References}

Abdullah, T. (2011). Indonesia dalam arus sejarah. Jakarta: PT. Ichtiar Baru Van Hoeve.

Adam, J. (2010). Communal Violence, Forced Migration and Social Change on The Island of Ambon, Indonesia. Belgia: Ghent University.

Alfulaila, N., Haryadi, Sudrajat, A., \& Nashrullah. (2019). The Effectiveness of Multicultural Approach in Writing Achievement of Indonesian Language Among Elementary School Students. Cakrawala Pendidikan, 38 (2), 366-376. https://doi.org/10.21831/cp.v38i2.23440 
Almisad, B. (2019). The Effects of Consept Mapping Instruction on Student's Attitudes, Motivations, and Self-Efficacy in Educational Technology Class. Internationa Journal of Learning and Developments, 9 (2), 1-13. https://doi.org/10.5296/ijld.v9i2.14529

Aman. (2011). Model Evaluasi Pembelajaran Sejarah. Yogyakarta: Ombak.

Anggraeni, I., Idrus, A., \& Anggraeni L. (2016). Implementasi Nilai-Nilai Wawasan Kebangsaan Berbasis Keorganisasian Mahasiswa dalam Meningkatkan Nasionalisme. Civicus: Jurnal Pendidikan Kewarganegaraan, $16 \quad$ (1), 12-29. https://ejournal.upi.edu/index.php/civicus/article/view/2917

Anis, M. (2017). Implementasi Wawasan Kebangsaan di Pondok Pesantren dalam Pembelajaran Sejarah di SMA Al-Muayyad Surakarta dan SMA Muhammadiyah Boarding School Yogyakarta. Jurnal Sriwijaya Historia, 1 (1), 1-10. https://jurnal.um-palembang.ac.id/index.php/jsriwijaya/article/view/669

Anwar, M.K. (2017) Pembelajaran Mendalam untuk membentuk Karakter siswa sebagai Pembelajar, Tadris: Jurnal Keguruan dan Ilmu Tarbiyah, 2 (2), 97-104. https://doi.org/10.24042/tadris.v2i2.1559

Arts, W., \& Gelissen, J. (2001). Welfare States, Solidarity and Justice Principles: Does the type Really Matter?. Acta Sociologica, 44, 283-299. https://doi.org/10.1080/000169990152696385

Banks, J. A. (2017). Diversity and citizenship education in multicultural nations. Multicultural Education $\quad$ Review, $\quad 1 \quad$ 73-88. https://doi.org/10.1080/23770031.2009.11102861

Beal, et al. (2014). Solidarity within a fixed community. Economics Letters, 125, 440-443. https://doi.org/10.1016/j.econlet.2014.10.023.

Budiwati, N. (2012). The Religious Life Harmony and the Nation's Integrity in History View. Jurnal Historia: International Journal of History Education, 8 (2), 275-294. https://doi.org/10.17509/historia.v13i2.6217

Chaiklin, H. (2011). Attitudes, Behavior, and Social Practice. The Journal of Sociology \& Social Welfare, 38 (1) 31-54. https://scholarworks.wmich.edu/jssw/vol38/iss1/3

Crow, G. (2002). Social solidarities, theories, identities and social change. Buckingham: Open University Press.

Davis, M. (2003). What's Wrong with Character Education?. American Journal of Education, 110, (1), 32-57. https://doi.org/10.1086/377672

Jones. (2009). Pengantar Teori-teori Sosial Jakarta: Yayasan Obor Indonesia.

Kinasih, K. P \& Dahliyana, A. (2018). Membangun solidaritas peserta didik melalui bakti sosial organisasi siswa Intra sekolah. Jurnal Sosioreligi, 16 (1), 22-28. https://ejournal.upi.edu/index.php/SosioReligi/article/view/10687 
Kochhar, S. K. (2008). Pembelajaran Sejarah. Jakarta: Grasindo.

Lexy J. M. (2011). Metodologi Penelitian Kualitatif. Bandung: PT Remaja Rosda Karya.

Lestari, S.U. (2018). Penanaman Nilai-Nilai Nasionalisme dalam Pembelajaran Sejarah Lokal Perjuangan Rakyat Sukorejo Kelas XI di SMA Negeri 1 Sukorejo. Indonesian Journal of $\begin{array}{llll}\text { History } \quad \text { Education, } & 6 & \text { (2), 205-215. }\end{array}$ https://journal.unnes.ac.id/sju/index.php/ijhe/article/view/27652

Lestariningsih, W.A. (2018). Penanaman Nilai-Nilai Multikultural dalam Pembelajaran Sejarah di SMA Negeri 1 Rembang Tahun Ajaran 2017/2018. Indonesian Journal of History Education, 2 (2), 123-131. https://journal.unnes.ac.id/sju/index.php/ijhe/article/view/27636

Loreto, J.M.D.L., Demate, A., Cruz, C.D., Perina, A.J., Paril, M. \& Esteves. (2019). A Phenomenological Study on the Challenges and Problems of New Social Studies Teachers. International Journal of Social Science \& Educational Studies, 6 (2), 23-40. https://doi.org/10.23918/ijsses.v6i2p23

Matsaganis, M. (2011). The welfare state and the crisis: the case of Greece. Journal of European Social Policy, 21 (5), 501-512. https://doi.org/doi: 10.1177/0958928711418858

Meeusen, C., Abts, K., \& Meuleman, B. (2019). Between solidarity and competitive threat?: The ambivalence of anti-immigrant attitudes among ethnic minorities. International Journal of Intercultural Relations, 71 (1), 1-13. https://doi.org/10.1016/j.ijintrel.2019.04.002

Miles, M. B dan Huberman, A. (2007). Analisis Data Kualitatif Buku Sumber tentang Metode-Metode Baru. Terjemahan Tjetjep Rohendi Rohisi. Jakarta: Universitas Indonesia.

Minelgaite, I., Blazyte, G., \& Littrell, R.F. (2017). Ethnicity and Occupational Differences. Pedagogika, 128 (4), 20-38. https://doi.org/10.15823/p.2017.52

Misbahudholam, A.R. (2016). Implementasi Pendidikan Multikultural Melalui Pendekatan Nilai Hulur Budaya dan Pancasila Untuk Membangun Karakter mahasiswa dalam Menghadapi Arus Globalisasi. Jurnal Teori dan Praktis Pembelajara IPS, 1 (2), 89-112. https://doi.org/10.17977/um022v1i22016p089

Najib, I.N.A. (2013). Penanaman Sikap Nasionalisme Melalui Mata Pelajaran Muatan Lokal Wawasan Kebangsaan Pada Siswa Kelas VIII di SMP N 1 Nglegok Kabupaten Blitar. Jurnal Pendidikan Kewarganegaraan, $\quad 2 \quad$ (1), $1-21$. http://mulok.library.um.ac.id/index3.php/59752.html

Nasikun. (2006). Wawasan Kebangsaan di bawah tekanan Globalisasi dan Kebangkitan Kembali Politik Aliran, Jurnal Ketahanan Nasional, 11 (1), 1-29. https://doi.org/10.22146/jkn.22106

Novianti, N. (2017). Teaching Character Education to College Students Using Bildungsromans. International Journal of Instruction, 10, 255-272. https://doi.org/10.12973/iji.2017.10415a.

Omar, N., Noh, M. A. C., Hamzah, M. I., \& Majid, L. A. (2015). Multicultural education 
practice in Malaysia. Procedia-Sosial And Behavioral Sciences, 174 (2), 1941-1948. https://doi.org/10.1016/j.sbspro.2015.01.859

Rahayuningsih, F. (2009). Pendidikan kewarganegaraan SD/MI kelas IV. Jakarta: Pusat Perbukuan Departemen Pendidikan.

Ricklefs, M. C. (2008). Sejarah Indonesia modern 1200-2008. Jakarta: Serambi Ilmu Semesta.

Saraswati, U. (2011). The Significance and Purpose of Ancient Manuscript for The Nation's Culture and Character Development Through the History Teaching. International Journal of History Education, 1, 97-116. https://doi.org/10.17509/historia.v121.12120

Seixas, P. (2005). Collective memory, history education, and historical consciousness. Historical Speaking, 7 (2), 17-19. https://doi.org/10.1353/hsp.2005.0046

Setiawan, J., Aman, \& Wulandari, T. (2020). Understanding Indonesian History, Interest in Learning History and National Insight with Nationalism Attitude. International Journal of Evaluation and Research in Education, 9 (2). http://doi.org/10.11591/ijere.v9i2.20474

Slameto. (2013). Belajar dan Faktor-faktor yang Mempengaruhinya. Jakarta: Rieneka Cipta.

Sofyan, F. S. (2017). Hubungan Mata Kuliah Jatidiri Bangsa Dengan Peningkatan WawasanKebangsaan dan Semangat Nasionalisme Mahasiswa (Studi Korelasi di Lingkungan Program Studi PPKN Universitas Buana Perjuangan Karawang). Jurnal CIVICS, 2 (1), 68-81. http://journal.ubpkarawang.ac.id/index.php/PPKn/article/view/268

Subaryana. (2012). The Impact of History Learning to Nationalism and Patriotism Attitudes in the Globalisation Era. Jurnal Historia: International Journal of History Education, 8 (1), 42-56. https://doi.org/10.17509/historia.v13i2.7697.

Sudaitmi, T., Subiyantoro, S. \& Sawitri. (2019). Governments's Impact Character Education Implementation Through Wayang Media: Lesson Learned From The State Senior High School 3 of Sukoharjo. IJSSHE: International Journal of Social Sciences, Humanities, and Education, 3 (2), 1-7. http://www.ijsshe.com/index.php/ijsshe/article/view/122

Suhady, I \& Sinaga. (2006). Wawasan Kebangsaan dalam Kerangka Negara Kesatuan: Modul Pendidikan dan Pelatihan Prajabatan Golongan III. Jakarta: Lembaga Administrasi Negara Republik Indonesia.

Sutomo. (2006). Metodologi Penelitian Kualitatif (dasar teori dan terapannnya dalam penelitian. Surakarta: UNS Press.

Vlekke, B. H. M. (2008). Nusantara sejarah Indonesia. Jakarta: KPG (Kepustakaan Populer Gramedia).

Wibowo, A. (2015). Manajemen Pendidikan Karakter di Sekolah. Yogyakarta: Pustaka Pelajar.

Wibowo, P. W., Wulandari, T., \& Setiawan, J. (2020). Relationship between the 


\section{Macrothink}

International Journal of Learning and Development

ISSN 2164-4063 2020, Vol. 10, No. 2

understanding of Indonesian history and the nationalism attitude of state senior high school students, 3 (1), 158-172. http://dx.doi.org/10.37500/IJESSR.2020.3014

Widayanti, P.K.W., Andayani, B., \& Arnawi, A. (2018). Wawasan Kebangsaan Siswa dan Implikasinya Terhadap Ketahanan Pribadi Siswa (Studi Pada Siswa Sekolah Menengah Atas (SMA) Umum Berasrama Berwawasan Nusantara, SMA Umum di Lingkungan Militer dan SMA Umum di Luar Lingkungan Militer di Kabupaten Magelang, Provinsi Jawa Tengah. Jurnal Ketahanan Nasional, 24 (1), 1-26. https://doi.org/10.22146/jkn.32229

Wulandari, T. (2010). Pembelajaran IPS Sebagai Media Penanaman Nasionalisme. Jurnal ISTORIA, 8 (1), 75-85. https://doi.org/10.21831/istoria.v8i1.3718

Zambeta, E. (2003). School and Religion. Athens: Themelio.

Zambeta, E. (2014). Education and Social Solidarity in times of Crisis: the case of voluntary shadow education in Greece. Education Inquiry, 5 (1), 24-58. https://doi.org/10.3402/edui.v5.24058

\section{Copyright Disclaimer}

Copyright for this article is retained by the author(s), with first publication rights granted to the journal.

This is an open-access article distributed under the terms and conditions of the Creative Commons Attribution license (http://creativecommons.org/licenses/by/4.0/). 